\title{
Анапластична великоклітинна лімфома, асоційована з грудними імплантатами
}

\author{
І. М. Мотузюк ${ }^{1}$, О. І. Сидорчук ${ }^{1}$, М. С. Кротевич ${ }^{2}$, П. Л. Понятовський ${ }^{1}$, Є. В. Костюченко \\ ${ }^{1}$ Національний медичний університет імені О. О. Богомольця, м. Київ, \\ ${ }^{2}$ Національний інститут раку, м. Київ
}

\section{Anaplastic large cell lymphoma, associated with the mammary gland implants}

\author{
I. M. Motuziuk ${ }^{1}$, O. I. Sydorchuk ${ }^{1}$, M. S. Krotevych ${ }^{2}$, P. L. Poniatovskyi ${ }^{1}$, E. V. Kostiuchenko ${ }^{1}$ \\ ${ }^{1}$ Bogomolets National Medical University, Kyiv, \\ ${ }^{2}$ National Cancer Institute, Kyiv
}

\begin{abstract}
Анапластична великоклітинна лімфома, асоційована з грудними імплантатами (BIA-ALCL), є рідкісною периферичною Т-клітинною неходжкінською лімфомою. Всесвітня організація охорони здоров'я внесла BIA-ALCL до класифікації нодальних форм Т-клітинних лімфом у 2016 р. [1]. Наразі питання діагностики BIA-ALCL та інформування як лікарів, так і пацієнтатів про можливе ускладнення після встановлення грудних імплантатів $є$ актуальним. В Україні хірурги, які займаються пластичною та реконструктивною хірургією, не знають про це ускладнення або не приділяють йому належної уваги, а самі хворі, як правило, звертаються саме до пластичних хірургів, а не до профільних спеціалістів.
\end{abstract}

Eniдеміологія. У всьому світі налічується 35 мільйонів пацієнтів з грудними імплантатами (майже 70 мільйонів імплантатів). Щоб підрахувати загальну кількість текстурованих імплантатів у всьому світі, вважається, що 97\% неамериканських імплантатів текстуровані, а 8\% імплантатів, що використовуються у США, також текстуровані [2].

Лише у 2016 р. у світі було виконано 1511117 естетичних та реконструктивних операцій на молочній залозі з наступним ендопротезуванням, тобто було використано близько 3 мільйонів імплантатів [3].

Відповідно до даних, зібраних Американським управлінням із санітарного нагляду за якістю харчових продуктів і медикаментів (FDA), наразі нараховується 414 звітів про BIA-ALCL серед більш як 10 мільйонів пацієнтів з грудними імплантатами у світі. Померли від згаданої патології 9 пацієнток [4]. У Франції зафіксовано 18 таких хворих [5], в Італії - 22 (1 померла) [6], у Великобританії - 41 (3 померли, 1 смерть підтверджена) [7], в Австралії - 72 [8] (3 померли) [9], у Нідерландах - 43 [10].

Фактори ризику. Встановлено чіткий зв'язок між виникненням цього захворювання та наявністю грудного імплантата. Кількість спостережень занадто мала для визначення інших факторів ризику виникнення цього за- хворювання, аніж наявність грудного імплантата. Із 414 звітів, представлених FDA станом на 2017 р., лише 272 (65,7\%) містили інформацію про поверхню імплантата: 242 (89,0\%) пацієнткам були встановлені текстуровані імплантати, 30 (11,0\%) - гладкі; 413 - інформацію про типи заповнення імплантатів: 234 імплантати були наповнені силіконовим гелем, 179 - фізіологічним розчином [4]. В Італії та Австралії 100\% пацієнтів мали текстуровані імплантати [6, 9]. У Нідерландах у 28 жінок було відомо про тип імплантата, 3 них у 23 (82,1\%) імплантати були текстуровані [10]. Відповідно до наведених даних у більш як 80\% пацієнток було встановлено текстуровані імплантати, що підштовхує до висновку, що ризик виникнення BIA-ALCL вищий у пацієнтів, що мають текстуровані імплантати. Про подібні дані повідомили G. S. Brody і співавтори [11]. BIAALCL виникає в проміжку від 3 до 14 років після операції (в середньому через 8 років), хоча є спостереження розвитку захворювання через 1 рік та 37 років $[4-6,9,10]$.

У кількох останніх публікаціях оцінено ризик розвитку BIA-ALCL у пацієнтів з текстурованими грудними імплантатами. За даними поточних досліджень BIA-ALCL може виникнути у однієї з 3817 - 30000 жінок з текстурованими грудними імплантатами [12].

Тактика лікування пацієнтів. Симптоматика BIA-ALCL неспецифічна. Більшість хворих звернулися до своїх лікарів зі скаргами на біль, потовщення, набряк або асиметрію грудей після встановлення імплантатів.

У пацієнтів з BIA-ALCL частіше виявляють спонтанне накопичення перипротезної рідини або капсулярну контрактуру в середньому через 8 - 10 років після грудного ендопротезування. Наявність функціональних або фізичних ознак (випіт, набряк, біль, запалення, серома, виразка), особливо через значний проміжок після ендопротезування грудних залоз, є підставою для виключення діагнозу BIA-ALCL [5].

Відповідно до результатів обстеження у пацієнтів з BIAALCL чутливість і специфічність ультразвукового дослі- 
дження (УЗД) щодо виявлення випоту становить відповідно 84 і 75\%, вузлового компонента - 46 і 100\%. У деяких спостереженнях УЗД виявилось більш інформативним, ніж комп'ютерна томографія (КТ) або магнітно-резонансна томографія (МРТ) [13]. Якщо за допомогою УЗД не вдається верифікувати діагноз або необхідне подальше його підтвердження, лікар може також використовувати МРТ або позитронно-емісійну комп'ютерну томографію (ПЕТ-КТ).

Рекомендується провести УЗД як первинне тестування випоту навколо імплантата або капсулярної контрактури, а також для вивчення стану лімфатичних вузлів. Якщо це обстеження недостантньо інформативне, тоді МРТ є наступним дослідженням [5].

У разі виявлення сероми чи випоту необхідно виконати тонкоголкову аспіраційну пункційну біопсію молочної залози для підтвердження діагнозу BIA-ALCL та виключення інших причин [5].

Діагностика сероми передбачає також стандартну культирувальну та цитологічну оцінку. Патологоанатом має повідомити про підозру наявності BIA-ALCL, щоб було застосовано фарбування за Романовським - Гімзою та проведено імуногістохімічне дослідження клітинного блоку для виявлення CD30 та маркерів анапластичної лімфомакінази (ALK). Наявність BIA-ALCL може бути підтверджена лише тоді, коли іiі виявлено разом із капсулою навколо імплантата або в межах випоту та підтверджено імуногістохімічним дослідженням як CD30-позитивний та ALK-негативний результат [14].

Будь-якій пацієнтці з діагнозом BIA-ALCL слід провести ПЕТ-КТ для виключення регіонального чи системного поширення захворювання. Якщо аномальний лімфатичний вузол виявлено в пахвовій ділянці, рекомендується його термінове гістологічне дослідження під час хірургічного втручання.

У разі капсулектомії або капсулотомії патологоанатом мусить проаналізувати будь-які підозрілі ураження (особливо там, де є ознаки запалення або будь-який випіт) $[15,16]$.

Лікування більшості пацієнток з локалізованою формою захворювання, яке обмежується капсулярною контрактурою, включає тотальну капсулектомію та видалення імплантата. Ад'ювантна терапія часто необов'язкова [17].

Пацієнти з генералізованою формою захворювання потребують агресивного системного лікування. В доповнення до капсулектомії та видалення імплантата потрібно застосовувати хіміотерапію та/або променеву терапію [17].

Ад'ювантна хіміотерапія виправдана у 2 - 18\% пацієнток 3 генералізованою формою хвороби, такою як метастази лімфатичних вузлів (Lugano stage II - IV; M. D. Anderson stage IIB - IV).

Для лікування системної ALCL застосовують схему CHOP як першу лінію [18]. Утім, згідно з міжнародними рекомендаціями лікарі мають змогу розглянути питання застосування схеми СНОР або альтернативної терапії брентуксимабом ведотином, який є кон'югатом токсину-антитіла до CD30, як препаратом першої лінії. Про результати застосування хіміотерапевтичних схем для лікування BIA-
ALCL судять за даними про випадки захворювання, однак у пацієнтів із метастазами в інші органи було досягнуто повної ремісії шляхом лікування брентуксимабом ведотином [19]. Даний препарат також може відігравати роль неоад'ювантного цільового агента для зниження рівня інвазії в грудну стінку [20, 21].

\section{Висновки}

1. BIA-ALCL - це рідкісна периферична T-клітинна лімфома, не до кінця вивчене захворювання, частота виникнення якого зростає. Результати дослідження вказують на необхідність інформування лікарів та пацієнтів щодо захворювання, проведення імуногістохімічного аналізу сером та подальшого вивчення цього захворювання.

2. Загалом прогноз щодо BIA-ALCL добрий, медіана виживаності пацієнтів коливається від 12 до 13 років. За 414 звітами про BIA-ALCL FDA зафіксовано смертність 2,17\%.

3. Через рідкість цих пухлин для пацієнтів з діагнозом BIA-ALCL потрібна узгоджена відповідь від пластичних хірургів, онкологів, рентгенологів та патологоанатомів. Клініцистам слід знати про зв'язок, який існує між грудними імплантатами та ALCL. Необхідні майбутні дослідження з метою розробки оптимальних інструкцій щодо профілактики, діагностики та лікування BIA-ALCL.

4. Розуміння та реалізація стандартизованого підходу до діагностики та лікування BIA-ALCL є важливими для своєчасного виявлення та попередження прогресування захворювання.

\section{References}

1. Swerdlow SH, Campo E, Pileri SA, Harris NL, Stein H, Siebert R, et al. The 2016 revision of the World Health Organization classification of lymphoid neoplasms. Blood. 2016 May 19;127(20):2375-90. doi: 10.1182/blood-2016-01-643569.

2. ASPS National Clearinghouse of Plastic Surgery Procedural Statistics 2016. Available from: https://d2wirczt3b6wjm.cloudfront.net/News/Statistics/2016/2016-plastic-surgery-statisticsreport. pdf.

3. International Society of Aesthetic Plastic Surgery Global Statistics. 2016. Available from: https:/www.isaps.org/wp-content/uploads/2017/10/ GlobalStatistics2016-1.pdf.

4. U.S. Food and Drug Administration. Anaplastic large cell lymphoma (ALCL) in women with breast implants. Medical device reports of breast implant-associated anaplastic large cell lymphoma. Available from: https://www.fda.gov/MedicalDevices/ProductsandMedicalProcedures/ ImplantsandProsthetics/BreastImplants/ucm481899.htm.

5. Breast implant-associated anaplastic large cell lymphomas. An experts opinion. The French National Cancer Institute. Available from: http:// www.ecancer.fr/content/download/119635/1429833/file/Breast $\% 20 \mathrm{im}$ plant-associated $\% 20$ anaplastic $\% 20$ large $\% 20$ cell $\% 201$ ymphomas.pdf.

6. Campanale A, Boldrini R, Marletta M. 22 Cases of Breast ImplantAssociated ALCL: Awareness and Outcome Tracking from the Italian Ministry of Health. Plast Reconstr Surg. 2018 Jan;141(1):11e-19e. doi: 10.1097/PRS.0000000000003916.

7. Medicines \& Health care products Regulatory Agency. Breast implants and Anaplastic Large Cell Lymphoma (ALCL). Available from: https:// www.gov.uk/guidance/breast-implants-and-anaplastic-large-cell-lymphoma-alcl.

8. Australian Government. TGA. Update - additional confirmed cases of anaplastic large cell lymphoma. Available from: https:/www.tga.gov.au/ alert/breast-implants-and-anaplastic-large-cell-lymphoma.

9. Loch-Wilkinson A, Beath KJ, Knight RJW, Wessels WLF, Magnusson M, Papadopoulos T, et al. Breast Implant-Associated Anaplastic Large Cell Lymphoma in Australia and New Zealand: High-Surface-Area Textured Implants Are Associated with Increased Risk. Plast Reconstr Surg. 2017 Oct;140(4):645-54. doi: 10.1097/PRS.0000000000003654. 
10. de Boer M, van Leeuwen FE, Hauptmann M, Overbeek LIH, de Boer JP, Hijmering NJ, et al. Breast Implants and the Risk of Anaplastic LargeCell Lymphoma in the Breast. JAMA Oncol. Accepted for Publication: 2017 October 10. Published Online: 2018 January 4. Available from: https://www.nvpc.nl/Uploads/jamaoncology_de_Boer_2018_oi_170081. pdf. doi: 10.1001/jamaoncol.2017.4510.

11. Brody GS, Deapen D, Taylor CR, Pinter-Brown L, House-Lightner SR, Andersen JS, et al. Anaplastic large cell lymphoma occurring in women with breast implants: analysis of 173 cases. Plast Reconstr Surg. 2015 Mar;135(3):695-705. doi: 10.1097/PRS.0000000000001033.

12. Clemens M. BIA-ALCL Resources By the numbers, and what they mean. 2018 March 21. Available from: https://www.plasticsurgery.org/ for-medical-professionals/health-policy/bia-alcl-physician-resources/by-the-numbers.

13. Adrada BE, Miranda RN, Rauch GM, Arribas E, Kanagal-Shamanna $\mathrm{R}$, Clemens MW, et al. Breast implant-associated anaplastic large cell lymphoma: sensitivity, specificity, and findings of imaging studies in 44 patients. Breast Cancer Res Treat. 2014 Aug;147(1):1-14. doi: 10.1007/ s10549-014-3034-3.

14. Kadin ME, Deva A, Xu H, Morgan J, Khare P, MacLeod RA, et al. Biomarkers provide clues to early events in the pathogenesis of breast implant-associated anaplastic large cell lymphoma. Aesthet Surg J. 2016 Jul;36(7):773-81. doi: 10.1093/asj/sjw023.

15. Clemens MW, Horwitz SM. NCCN Consensus Guidelines for the Diagnosis and Management of Breast Implant-Associated Anaplastic Large Cell Lymphoma. Aesthet Surg J. 2017 Mar 1;37(3):285-9. doi: 10.1093/ asj/sjw259.
16. Kim B, Predmore ZS, Mattke S, van Busum K, Gidengil CA, et al. Breast implant-associated anaplastic large cell lymphoma: updated results from a structured expert consultation process. Plast Reconstr Surg Glob Open. 2015 Feb 6;3(1):e296. doi: 10.1097/GOX.0000000000000268.

17. Aladily TN, Medeiros LJ, Amin MB, Haideri N, Ye D, Azevedo SJ, et al. Anaplastic large cell lymphoma associated with breast implants: a report of 13 cases. Am J Surg Pathol. 2012 Jul;36(7):1000-8. doi: 10.1097/ PAS.0b013e31825749b1.

18. Horwitz SM, Zelenetz AD, Gordon LI, Wierda WG, Abramson JS, Advani RH, et al. NCCN guidelines insights: Non-Hodgkin's lymphomas, version 3.2016. J Natl Compr Canc Netw. 2016 Sep;14(9):1067-79.

19. Zimmerman A, Locke FL, Emole J, Rosa M, Horna P, Hoover S, et al Recurrent systemic anaplastic lymphoma kinase-negative anaplastic large cell lymphoma presenting as a breast implant-associated lesion. Cancer Control. 2015 Jul;22(3):369-73. doi: 10.1177/107327481502200317.

20. Johnson L, O’Donoghue J, Stark H, McLean N, Turton P, Khan AA, Turner SD, et al. Breast implant associated anaplastic large cell lymphoma (BIA-ALCL): The UK experience and first reported case of neoadjuvant brentuximab. Cancer Res. 2017;77(Suppl):Abstract P5-03-02. doi: 10.1158/1538-7445.

21. Richardson K, Alrifai T, Grant-Szymanski K, Kouris GJ, Venugopal P, Mahon B, et al. Breast implant-associated anaplastic large-cell lymphoma and the role of brentuximab vedotin (SGN-35) therapy: A case report and review of the literature. Molecular and Clinical Oncology. 2017;6(4):539-42. doi: 10.3892/mco.2017.1170. 